\title{
Being a Young High School Teacher in Mexico City. Teachers' Experiences in Times of Pandemic
}

\author{
Luis Antonio Mata Zúñiga ${ }^{1}$ (D) Diego Angeles Colin²
}

Received: 6 July 2021 / Revised: 16 November 2021 / Accepted: 17 November 2021 /

Published online: 30 November 2021

(C) The Author(s), under exclusive licence to Springer Nature Singapore Pte Ltd. 2021

\begin{abstract}
This work discusses the educational and occupational challenges posed by the outbreak of the COVID-19 pandemic from the point of view of young high school teachers from Mexico City. We sought to identify and compare their teaching practices using the concept of asymmetric educational spaces (Villa Lever et al., 2017) to capture the influence of educational inequalities upon this sector's response to the health crisis. For this purpose, 22 semi-structured interviews were conducted to an intentional selection of cases from private and public high schools, all from ages 22-30. Interviews were conducted remotely between June and August 2020, the moment of the first wave of COVID-19 infections in the Mexican capital. Drawing on Hochschild's work (1983), we deploy the concept of "asymmetric educational labours" to show how different institutional resources and social contexts of action shaped the emotional experiences of our informants. Furthermore, this research provides significant insights into the multiple problems experienced by young early career teachers as a social group with little visibility in times of crisis.
\end{abstract}

Keywords Teachers $\cdot$ Inequalities $\cdot$ High school $\cdot$ COVID-19

\section{Introduction}

The COVID-19 pandemic has created an unparalleled educational crisis across the globe. With the World Health Organization declaring a pandemic on $11 \mathrm{March}$ 2020, many national educational systems suspended face-to-face teaching to enhance social distancing and mitigate the spread of the virus, putting at risk the

Luis Antonio Mata Zúñiga

antomata@comunidad.unam.mx

Diego Angeles Colin

dangeles9@gmail.com

1 Universidad Nacional Autónoma de México, México, México

2 University College London, London, England 
school progression, academic achievement, and emotional health of more than 1.5 billion students of all ages (OECD 2021; UNESCO 2020). To this must be added the challenges teachers and teaching assistants have undergone in the wake of the COVID-19 crisis. They have seen their teaching practices and daily routines at school and their occupational careers and personal well-being jeopardised. Episodes of stress, confusion, and burnout have been identified among teachers in the wake of the educational crisis, especially during the sudden transition to online activities (Cervantes-Guevara et al. 2021; Kim and Asbury 2020; Klaproth et al. 2020). This paper seeks to explore these experiences from the point of view of young high school teachers from Mexico City, a social group with little visibility in times of pandemic. We frame our analysis as a comparative study of two distinctive school settings characterised by asymmetric resource provision and opportunity structures (Villa Lever et al. 2017). The main argument pursued by this work is that the experience of the educational crisis is mediated by different factors, such as the resources and opportunities available in specific settings (education, occupation, household, etc.) We deploy the concept of asymmetric educational labour to show how different institutional resources and social contexts of action shape the emotional experiences of a given crisis. Besides, our data shows how emotionally charged was the experience of the educational crisis for both young teachers, in their roles as workers within an emotionally demanding occupation (Bodenheimer and Shuster 2020; Tsang 2013), and young students.

\section{The Educational Crisis in Context}

In Mexico, authorities declared the suspension of classes for all educational stages on 23 March 2020, bringing to a halt the activities of more than 37.5 million students and 1.2 million teachers (INEGI 2020; UNESCO 2020). While a TV-based home learning program for the primary and secondary levels, known as Aprende en casa (Learn at home), was put in motion within a few weeks and classes in the upper-secondary and higher education levels were quickly adapted to online platforms, there have been alarming setbacks within the Mexican educational system. According to official estimations, $2.2 \%$ of students enrolled in any form of education during the 2019-2020 academic year did not complete their academic programs, while roughly 5.2 million Mexicans in ages 3-29 did not enrol the following term either for health or economic reasons (INEGI 2021).

We focus our attention on the upper-secondary education (USE) level for one particular reason. Up to date, USE holds the highest drop-out rate during the pandemic within the Mexican compulsory education system (12 years of schooling). Just during the 2020-2021 academic year, nearly 1.9 million adolescents in ages 16-18 were out of school, representing 33.3\% of the cohort (INEGI 2021). We believe that any research agenda on drop-out in USE in the context of the ongoing health crisis must include the view of teachers and their struggles in coping with student retention and drop-out. This paper seeks to contribute to this end 
by foregrounding the experiences of high school teachers during the transition to online education and their perceptions of their students' struggles in adapting to remote learning. We are particularly interested in exploring the emotional weight of both school closures and transition to online education during Spring 2020 and the intersection between the educational crisis and educational inequalities.

Research in the Mexican context has explored general trends among teachers from one single institution or within one educational sector. In our case, we have opted to explore the private and public educational sectors due to the significant asymmetries of resources and opportunities existing between them (Villa et al. 2017; Saraví 2015). We argue that the distinction between public and private education articulates not only different opportunities structures within the contest of the COVID-19 pandemic but also ways of experiencing it and reacting to it as teachers. Thus, we undertake a comparative perspective between teachers from public and private institutions to assess whether there are major differences from one context to the other.

\section{Theoretical Framework}

The striking levels of social inequalities in Latin America have led some local social researchers to speak of "fragmented societies" which are underpinned by highly differentiated, disconnected, and at times excluding, circuits of schooling, consumption, residence, and work (Bayón 2015; Saraví 2015; Krüger 2011; Kessler 2002). In seeking to apprehend how educational opportunities were distributed across Mexico City's fragmented university system, Villa Lever and colleagues (2017) developed the concept of Asymmetric University Spaces (AUS). According to the authors, the rapid expansion of the demand for higher education in Mexico over the last few decades, along with the increasing influence of educational trends from abroad, such as the push for internationalising education, led to the development of a myriad of new institutions with varying degrees of quality and academic capacities, producing a highly stratified university field. Within this context, the authors use the concept of AUS to account for one distinctive way the Mexican higher education system contributes to the reproduction of social inequalities: the AUS alludes to the numerous inequalities at the material and symbolic level between Mexican academic centres, from the quantity of material and academic resources to the qualities of the academic offer and the institutions' reputation, that generate institutional hierarchies. According to the authors, these asymmetries produce not only different educational outcomes (seen, for example, in levels of achievement, progression, or graduation across institutions) but also different sets of opportunities among students, such as the increasingly differentiated inclusion of adolescents from low socioeconomic backgrounds into higher education.

In this work, we reframe the concept of AUS as Asymmetric Educational Spaces (AES) to characterise upper secondary education in the Mexican capital. In Mexico, USE represents a very diversified system organised around different curricular modalities - such as the bachilleratos generales (comprehensive schools) that 
prepare students for higher education and technological and professional schools that usually grant terminal degrees-and different levels of organisational jurisdiction and academic autonomy, with some high schools operating under the umbrella of higher education establishments. However, no other institutional consideration puts in evidence better the stark institutional asymmetries within the USE system than the public and private divide.

To start with, public high schools, which account for nearly $85 \%$ of the student population in USE (Mejoredu 2020), are fee-free and tend to be more dispersed across the national territory, giving special attention to the educational demand of rural municipalities mainly through at-distance modalities. Conversely, private institutions operate as for-profit organisations and are established mainly in metropolitan and recently urbanised areas, offering almost exclusively face to face education. These economical, spatial, and symbolic configurations carry within a strong class gradient: students from public institutions, particularly from technical and atdistance modalities, come much more frequently from disadvantaged contexts than those from private institutions (Binelli and Rubio 2013; Villa Lever et al. 2017). Additionally, the number of students from indigenous backgrounds is much higher in the former than in the latter (INEE 2013). The interplay of such asymmetries is reflected in some educational outcomes. For instance, a recent assessment of high school students at a national level (known as PLANEA) shows that private high schools and public high schools associated with a higher education institution tend to outperform their peers from comprehensive and technical high schools (INEE 2017).

We further argue that teachers are also subjected to the influence of these asymmetries since their teaching practices, labour conditions, and experiences are strongly influenced by the level of resources and quality of infrastructure within each type of school. An official report in 2012 revealed that classrooms were not spacious enough to accommodate all students in $70.7 \%$ of public comprehensive high schools in comparison to $23.4 \%$ of private high schools. Additionally, $91 \%$ of public high schools could not satisfy the student demand for computers against $28 \%$ of private establishments (INEE 2013). At the teaching level, while headteachers and teachers at both public and private high schools possess similar levels of qualifications and professional experience (nine in ten have undergraduate diplomas at the minimum), teachers at public establishments tend to have much larger classes and lead more groups per term than their counterparts at private high schools (ibid.).

In this work, we seek to show how these asymmetries affect young teachers' experiences, especially in relation to their challenges posed by the COVID-19 pandemic, expanding thus the scope of the asymmetries captured by the AES towards subjective asymmetries. As Saraví (2015) argues, in Mexico, the public and private distinction implies significant differences in the ways education is subjectively lived: "Different types of educational patterns, expectations and values are produced and reproduced in each of these two types of schools. But also, different kinds of social relationships, subjectivities, and non-academic abilities such as communication skills, confidence, or global knowledge are embodied in their students" (p.159).

To this end, we rely on the concept of emotional labour (Hochschild 1983) to capture the affective dimension of the teaching profession in contexts of crisis and 
deep institutional asymmetries. Hochschild (1983) coined the term emotional labour to refer to the control of one's emotional states in order to influence the emotional responses of others. Across different contexts, teaching has been recognised as an occupation that demands a high level of emotional investment and restraint in order to achieve expected results among students or to conduct their relationships with them within classrooms (Kinman et al. 2011; Brennan 2006; Hargreaves 2000). A recent study among high school teachers has shown that those who tend to fake their emotions during class tend to induce students' engagement in their learning more frequently (Buric and Frenzel 2020). Increasing stress and fear levels associated with work overload and COVID-19 spread have also been reported among Mexican high school teachers (Cervantes-Guevara et al. 2021; Mejoredu 2020).

Adding to this, it has been argued that emotional or affective labour is a key characteristic of the occupations that fall within the so-called "service sector" of the economy, such as teaching, which are occupied mostly by young people (Farrugia et al. 2018). According to official statistics, one-third of high school teachers in Mexico are under the age of 34 , being more prevalent in private high schools at $44 \%$ (INEE 2019). Thus, it can be expected a high level of emotional demand within this teaching sector.

While the emotional labour of teachers and young workers has been analysed from numerous perspectives, it has not yet been studied in a comparative perspective that focuses on the influence of institutional asymmetries of resources and socioeconomic conditions. We expect that our work contributes advancing more comparative studies of young workers and teachers across different institutional contexts and structural conditions, as well as studies of emotional labour in contexts of crisis at different scales (global or local).

\section{Methodology}

This work used a qualitative approach to identify the experiences of young teachers in Mexico who work in public and private high schools in the context of social distancing imposed by COVID-19 in 2020. We sought primarily to describe and compare the asymmetries and inequalities accompanying teaching activity in different school spaces.

Twenty-two semi-structured interviews were conducted remotely through the platform ZOOM to protect the informant's social distancing practices and health. Interviews were held between June and August 2020. All interviewees were invited to volunteer to take part in the research through email. The average length of the interviews was 45 min.

The delimitation of the studied population followed the theoretical and "snowball" selection method (Ruiz 1999), where the main interest is to achieve a better understanding of the phenomenon through the information provided by selected interviewees (Bertaux 1997) who best represent the plurality of ideas and perceptions around the object of study. For this purpose, the following criteria were used: (a) being between ages 21 and 31, (b) living in Mexico City at the start of the 
pandemic, (c) working in local public or private institutions, (d) developing classes regularly (having at least one group in charge), (e) and that the interviewees had been in-person high school teachers before the pandemic. Our final sample included 12 male and ten female interviewees and had equal representation of private and public schools.

All interviews were analysed applying thematic analysis (Braun and Clarke 2006). Transcripts were coded in Atlas.Ti program version 9.0 considering some predefined categories (e.g., teaching practices before the pandemic, teaching practices after the pandemic) and those that emerged throughout the global analysis of the interviews.

\section{Results}

At a broad angle, the results of our analysis show that our informants initially shared similar challenges in the wake of school closures and transition into online education caused by the spread of COVID-19. The first of these was the sudden adaption of face-to-face classes to online teaching. The interviews reveal that most of the interviewed teachers received training to use various digital platforms. In second place, they report that the principal interest of the schools' leaderships was to avoid student drop-out. Interestingly, one of the most common strategies towards student retention reported by most of our informants was related to the management of emotions: they were suggested to show empathy for their students' emotional needs given the sudden appearance of the pandemic.

In this scenario, teachers from both educational spaces had to constantly correct their students' assignments to avoid failing subjects as much as possible. As a result of this routine practice, teachers reiterate fatigue, stress, and a feeling of being alone to face the problems they experienced with their students. Also, in both cases, many situations of institutional control by their hierarchical superiors stand out, either to verify that they developed online education under the guidelines established by the school or through constant calls to meetings as part of the administrative control in the schools. It was very frequently, especially at the first months of the pandemic, that teachers experienced a feeling of being connected and available all the time to their superiors through mail or WhatsApp, or by platforms notifications by their students, and if they do not do so, they could earn a warning from their superiors or worse.

Although most of our interviewees mentioned enjoying being teachers during this period and that the relationship with their students was usually good, many mentioned that the experience of teaching online in the context of a pandemic distance them from their students. Some attitudes of disinterest of the students about the contents of the subjects they teach, and above all keeping the camera off, encouraged several teachers to question their teaching work. They frequently asked themselves: 'what can you do to improve your classes and capture your students' interest while avoiding awkward silences? Or how they could motivate the class participation and hooked the students with the content as happened in face-to-face classes?', as one informant put it. 
Despite these commonalities, the interviews reveal striking contrasts in the institutional conditions within which the teachers' transition to online education and their coping strategies were developed. As asymmetric spaces, private and public institutions offered different solutions material and symbolic conditions to face the educational crisis, shaping the emotions and experiences of our teachers.

\section{Asymmetric Educational Spaces, Asymmetric Emotional Labours}

All interviewees were teaching in private high schools and described their working environment in very similar ways before the pandemic. We learn that their schools had ample access to educational technologies and online resources such as computers and learning platforms. This is the case of Daniel (31 years old), whose institution had made a significant investment in new equipment a few months before the pandemic started, upgrading all classrooms with lavish intelligent boards, projectors, and sound systems while also offering all teachers the opportunity to purchase individual devices through the school's credit account. Consequently, all interviewees from private schools were already acquainted with such resources before faceto-face teaching was suspended and especially that they did not find it hard to adapt to the new teaching conditions. Even more, in some cases, their lessons were already reliant on online platforms for teaching or assessment purposes, making the transition even smoother. For instance, Lizette (30 years old), a music teacher, had often used the platform "Classroom" to deliver some of her regular lessons and to communicate with her students. When she was notified that this platform would be the main means of teaching, she adapted her lessons to the platform's requirement without any significant difficulty and in a very short time.

By contrast, the adaptation to at-distance teaching in public schools was much more troubled due to the lack of technological resources. For instance, in a comprehensive high school, resources were far from satisfying the demands of the day-today activities before the pandemic started: "Even us, teachers, do not have access to computers", our informant mentions, "and when we do, we use our personal computers. The only projector in the school had to be shared between about 20 teachers".

To this must be added the favourable socioeconomic conditions among students from private schools, which resulted in a wide availability of technological resources at home and skills, according to our interviewees' perception. On the other hand, students in public high schools tend to have more socioeconomic disadvantages than their peers at private institutions. In some cases, economic limitations can be very prevalent. The same informant found these circumstances particularly difficult to reconcile in light of her new teaching environment: "I think that $20 \%$ of them (her students) have a computer, I don't exaggerate. And it might be less, actually. The majority of them use smartphones to work, and most of the times, these are not even theirs. They might belong to their moms or dads. I had this student who told me once: "I can't download Teams, teacher, my mom's phone doesn't have enough capacity, and I don't know what to do".

In this context of sheer inequalities between private and public schools, our interviewees experienced the transition to at-distance education and lockdown during 
spring 2020. As we will see, the uneven availability of resources between the two educational sectors, and particularly among their respective student communities, conditioned the interviewees' main concerns on their students and teaching practices.

\section{Private High Schools: Dealing with the Students' Emotions}

Many of our interviewees from private schools identified their students' emotions as their main concern during the first weeks of school closures. After re-establishing interaction with their classes during the first days of lockdown, our informants started learning from their pupils that their situation at home was not as pleasant as they had expected. Issues such as difficult interactions between family members or stress about the pandemic became a common complaint. In some cases, interviewees heard about severe cases of depression and anxiety among the students. Within few weeks after transitioning into at-distance education, some students started missing their online classes and, in some cases, education was abandoned.

For some interviewees, many of the situations their students were facing during the initial stages of lockdown were related to their age situation and relationships with parents. Lilia, a history teacher, says of her class: "I think that for them being an adolescent was challenging enough. Some of them had a tough time with their own families. And in some cases, it was very obvious. For example, at the (institute) we had some parents expressing serious concerns for their own children: "we got no idea what to do to make him do his homework, we can't convince him of doing any of his lessons, and we can't communicate with him'. Now add to this isolation, like them not seeing their friends, not having their day-to-day routines, not going out. That must have been very complicated for them".

For other interviewees, their students' emotional turmoil was grounded primarily in the sudden adaptation to online activities and all that this implied. Miguel (30 years old), a social sciences teacher, recall: 'They weren't ready to go from a face-to-face model to an at-distance one in such a short time. Suddenly they were in videoconferences from eight (in the morning) to one (in the afternoon), and then lots of homework. It was a whole new academic lifestyle to assimilate'. He continues: 'they got overwhelmed with all these activities very rapidly. And if the teacher didn't offer enough support, they would start lowering their grades or simply unenrolling from school, saying: 'I can't do this anymore'.

Against this broad context at private institutions, the interviews show that both school administrations and teachers had to rapidly design strategies to support students in coping with anxiety and depression to reduce the incidence of underperformance and school drop-out. In the case of our eleven interviewees from the private school sector, online classes and homework were reduced to avoid burnout situations, while assessments had to be relaxed if not suspended at all. For many interviewees, this meant that their teaching practices had to change on repeated occasions to adjust to the students' changing context. Interestingly, some of our interviewees perceived that school closures transformed their roles as teachers. For instance, Eric ( 27 years old), a biology teacher, tells us that by the end of the first 
term in lockdown (summer 2020), he was dedicating more time to counselling his students than teaching them biology lessons. He recalled a special occasion when all his students approached him at the end of an online class to desperately express their dissatisfaction with lockdown and school closures: "they would tell me "we want to go back to school, professor, we are tired of this". So, all I did was to tell them 'I am listening to you', he then adds: 'they thought I had something to tell them afterwards, but I just wanted to listen to them. I asked them to express anything they wanted to'.

\section{Public High Schools: the Weight of Economic and Emotional Needs}

Unlike their peers at private schools, our interviewees from public institutions encountered a more precarious scenario. Indeed, many interviewees coincided that their main problem during the transition to at-distance activities was the lack of technological resources among their students or the low quality of these, such as a restricted bandwidth of the internet at home. These shortages forced our interviewees to devise numerous strategies to allow as many students as possible to access their lessons in the most efficacious way. Significantly, almost all our interviewees relied on asynchronous teaching methods, such as video-recorded lessons, to continue teaching.

The case of Raúl, a 26-year-old English teacher, sums up succinctly the perils that many of our informants described during the interviews. Raul noticed his students' limitations very early as many of them were not attending his online lessons. He states: 'Many of my students did not have a computer. They had to work from their cell phones using the paid mobile data service. They would even send me their homework on WhatsApp'. However, like most of our interviewees from public institutions, Raul had to find a way to carry on his teaching duties. 'Despite these problems, we had to keep teaching. We had to be creative, like uploading classes online, making podcasts, finding a way to help them, and let them know that we cared. I consider that it is also part of my work'.

Despite the efforts of teachers like Raul, school drop-out became more frequent over time. According to our interviewees, many of their students started combining work and study simultaneously, with the eventual consequence that some of them stopped submitting their assignments and attending classes. Raúl, as well as other public high school teachers, highlighted in their interviews that the school achievement in their students was low and that there was a noticeable difference between those who had access to technological devices and connectivity compared to those who did not. In the face of this situation, our informants found themselves forced to make their evaluations more flexible, as in the case of their peers at private institutions.

Furthermore, the interviews show that the school administration knew the perils public teachers were experiencing with their students. School leaders instructed teachers to save as many students as they could, meaning that they should play an active role in avoiding school drop-out. In this sense, interviews 
with public school teachers show that headteachers frequently asked our interviewees to telephone those students who were no longer attending online lessons and this way to find out why this was happening. Once in contact, teachers were suggested to motivate students to continue with their studies. As Jussel (30 years old), a professor of communications, recalled:

'Our supervisors asked us to report if we had students with sick relatives or if they were sick. We had to talk to them on the phone, send them emails, or look for them through their classmates to get them back to class. In addition to the classes, we had to make weekly reports of how many students we had recovered'.

This kind of relationship with the headteachers and with their students elaborates a significant emotional tension in the interviewees during the transition period to online teaching, as Jussel states:

'I didn't mind having many students and having to review their assignments and resubmit them for correction. What bothered me was that I had to correct all the time through the platform and always be empathetic with them because, from the school's administration, the direction was "they must not fail, we must concentrate our efforts to avoid drop-out". At the same time, I had to take 50-hour training sessions, 3 hours a day, to use platforms for online education. It was exhausting work; the school administration constantly told us we should be empathetic with our students, but I felt that the school was not empathic with me. My payments were delayed, I did more administrative work to help the students to not leave school, and I had to adjust to their problems. But I felt that my effort was not important for the school, neither financially nor emotionally. The main problem at the beginning was the transfer of face-to-face education to online education and thinking fundamentally about students, and later we all understood that it had to be done differently, and things changed. But at first, in those work conditions, I thought about quitting because of the stress and felt that my problems were not important for the school'.

According to other interviewees, the time they spend calling and mailing to the absent students and also the weekly meetings with school authorities (which were not held during face-to-face classes) to discuss the situations they experienced about distance education sometimes took more time than they used to prepare and carry out their classes. This "new normal" produced more stress and discomfort to the already experienced because of social distancing and the pandemic. Nicolas (27 years old), a professor of social sciences, recalled: 'The school wants us to handle online classes the way we used to do before [when the classes were faceto-face], but this is impossible, especially for our students. I am not happy telling you this, but I think that the school leadership is more concerned on giving the appearance that they still have control than in the community itself'.

Teachers from public institutions have more class hours in the same school and have longer teaching seniority than most private teachers. Typically, in a semester, 
they are in charge of five or six groups; this represents an average population of between 250 and 300 students. Perceptions about their students tend to describe the contexts of economic precariousness and technological difficulties to continue with their classes online. Unlike the narratives that private teachers recover from their students, in the case of public teachers, it is usual for the latter to talk about students who are going through difficult situations at home because their parents lost their job, that their relatives and themselves they caught COVID, and have even lost loved ones because of the disease.

Natali (29 years old), a vocational guidance teacher and Tutor at school, states: 'Some of my students have fallen ill, and others have lost relatives due to COVID [...] Many do not have the material or emotional conditions to continue studying, but still keeps doing it. Some tell me that they feel they are not learning, and I can see that their performance is deficient compared to how they should be in face-toface classes. [...] I think they feel very insecure about their future, that the pandemic is holding them back a lot'. This perception about their students is common among public school teachers. At the moment of the interview, they highlight an open uncertainty regarding when they will be able to return to face-to-face classes and under what conditions they will return. Students and teachers see the future is crossed by uncertainty about school and how the world will be like afterwards. In public school communities, the pandemic has made itself felt more in the body and in the subjectivities of its members, many of whom continue to attend classes and carry out their assignments as a form of resistance in the face of the difficulties they experience every day.

\section{Concluding Remarks}

The COVID pandemic has caused crises across nations, affecting people's lives, health, jobs, and education, and Mexico is no exception in this regard. According to different sources, as of spring 2021, Mexico had the fourth-highest number of confirmed deaths worldwide and the third-highest excess mortality rate (Secretaría de Salud 2021; Palacio-Mejía et al. 2021). At the same time, the reduction of economic activities across the country that came with the Federal government's "stayat-home" contentious policy caused the national economy to shrink by $8 \%$ during 2020 (OECD 2020). The pandemic's impact on the Mexican educational system is no less severe. According to official estimations, one in ten students in school during the 2019-2020 academic year did not return to classes the following year, with USE having the most considerable incidence of school drop-out of all educational levels (INEGI 2021).

However, our work shows how different responses to the educational crisis were in the Mexican context and the emotional experiences emanating from the educational conditions in which actors such as teachers and students operated. The interviews show a stark contrast in resources and experiences between private and public schools, much in line with official reports that point to significant inequalities in the infrastructure and educational resources between the two sectors (INEE 2013). 
Indeed, our interviewees' accounts offer us a bleak educational panorama shaped by profound social and institutional inequalities, particularly in the case of public institutions. The lack of computers, connectivity, and other technological resources in public high schools had affected not only our interviewees' teaching activities before the pandemic but has also influenced to a large extent the way they made the transition into at-distance activities once face-to-face interactions were suspended.

In this context of deep institutional asymmetries, our informants coped with the diverse emotional experiences arising from their profession. As it has been argued, teaching is an occupational activity emotionally charged (Bodenheimer and Shuster 2020; Tsang 2013), and there is evidence of heavy emotional demands during the context of the COVID pandemic (Cervantes-Guevara et al. 2021; Kim and Asbury 2020; Klaproth et al. 2020). We also saw that one of the main demands posed to many of our interviewees, regardless of their educational space, was emotional in nature: being empathetic to students, an activity we categorise as emotional labour (Hochschild 1983).

Nevertheless, in this paper, we set out to illustrate how different sources of such emotions and experiences can be linked to the different layers of inequality surrounding us. In this case, we use the concept of AES to capture the diverging conditions in which Mexican high schools function as well as to make sense of the context upon which responses to the educational crisis caused by COVID-19 were deployed. In light of the existing asymmetries between private and public schools, we observe two different ways of experiencing the initial stage of school closures in the Mexican context, which we refer to as asymmetrical emotional labours. On the one hand, teachers from private institutions had various technological resources at their hands and were somewhat acquainted with some online platforms from which they built their online classes and activities. Significantly, their main concerns during the transition to at-distance activities during Spring 2020 were centred around their students' emotional well-being since the availability of technological and other material resources among them did not seem to be a significant issue. Thus, in this context, there seemed to prevail feelings of frustration emanating primarily from the students' indifference to online platforms and teaching. Ana (22 years old), one private high school teacher of literature, illustrates this: "What was terrible about it [online teaching], and maybe it was worst of it, was seeing two or three cameras open after the class had finished. There wasn't anyone behind them. I mean, they [the students] left their cameras and microphones opened and simply went away without any concern for the class" - she adds with an exasperated voice - I became very cynical about this, like [suggests she is talking to her students] 'if you don't want to be here, then don't'.

On the contrary, teachers from public institutions were more limited in resources from the very beginning of the pandemic. Although they did have different resources at their disposal, such as online resources and platforms, they were not always familiarised with their use, yet the most determining factor shaping their transition into at-distance education was their students' circumstances. In this case, the first problem that teachers faced when moving from classroom education to online education was knowing that their students attended classes from their cellphones because they did not have computers or because there were 
not enough electronic devices at home, in addition to other technological problems. However, it was indeed an inconvenience for teachers to check homework and develop classes through the platforms in a synchronous way; it forced most of them to understand their teaching activity from another point of view, having a better understanding of their students, which some of them made a real effort to attend classes and continue studying. Situations like these have made young teachers practice another form of teaching, not in a technological way, but more empathetic and comprehensive with their students. Undoubtedly, the pandemic crisis will force us to rethink teaching from a different position.

It is remarkable that our interviewees were young people who at that moment were defining to continue teaching, dedicate themselves to another professional activity, or continue with their postgraduate studies. The opportunities and constraints experienced in this historic event will profoundly mark a new generation of teachers, and we hope it will be for good.

It is not possible yet to identify the pandemic's implications on education, but it is essential to address the lessons it has left us. It is imperative to guarantee access to the internet as a human right; access to education and its possibilities in virtual environments cannot be mediated by a set of companies that operate under the logic of the market. The access and consumption of technology cannot be exclusive to the most favoured sectors. The State's work must focus on improving the socioeconomic and technological conditions of the most vulnerable school communities to guarantee that access to online education is of quality for all. The global reality in which the pandemic has placed us calls for thinking about education from a new social perspective, in which it is essential to recognise and combat the educational inequalities that have been accentuated during the pandemic.

\section{Limitations of Study}

This study was conducted with a small selection of teachers from different institutions to capture broad trends between the private and public sectors at the USE level. Interviews addressed primarily the transition period from face-to-face teaching to at-distance activities in Mexico City. Given the lengths of school closures in the Mexican context, more research is needed on teachers' educational practices and overall experiences from a more longitudinal perspective. We hope this research offers a roadmap for further examinations of educational inequalities in the context of the pandemic from both the teachers' and students' perspectives.

\section{Declarations}

Informed Consent All interviewees agreed to participate in this study under the promise of confidentiality.

Conflict of Interest The authors declare no competing interests. 


\section{References}

Bayón MC (2015) La integración excluyente. Experiencias, discursos y representaciones de la pobreza urbana en México, Universidad Nacional Autónoma de México y Bonilla Artigas Editores, México, $178 \mathrm{pp}$.

Bertaux D (1997) Les récits de vie: perspective ethnosociologique. Nathan université.

Binelli C, Rubio M (2013) The Returns to Private Education: Evidence from Mexico. Econ Educ Rev 36:198-215. https://doi.org/10.1016/j.econedurev.2013.06.004

Bodenheimer G, Shuster S (2020) Emotional labour, teaching and burnout: Investigating complex relationships. Educational Research 62(1):63-76

Braun V, Clarke V (2006) Using thematic analysis in psychology. Qual Res Psychol 3(2):77-101. https:// doi.org/10.1191/1478088706qp063oa

Brennan K (2006) The managed teacher: emotional labour, education, and technology. Educational Insights 10:55-65

Burić I, Frenzel AC (2020) Teacher emotional labour, instructional strategies, and students' academic engagement: a multilevel analysis. Teachers and Teaching, https://doi.org/10.1080/13540602.2020. 1740194

Cervantes-Guevara G, Maciel-Saldierna M, Elizondo-Hernández E et al (2021) Fear of COVID-19 in high school personnel: a survey study in western Mexico. Int J Ment Health Addiction. https://doi. org/10.1007/s11469-020-00473-z

Farrugia D, Threadgold S, Coffey J (2018) Young subjectivities and affective labour in the service economy. J Youth Stud 21(3):272-287

Hargreaves A (2000) Mixed emotions: teachers' perceptions of their interactions with students. Teach Teach Educ 16(8):811-826. https://doi.org/10.1016/S0742-051X(00)00028-7

Hochschild AR (1983) The managed heart: commercialisation of human feeling. University of California Press, Berkeley

INEE (2013) La Educación Media Superior en México. 2a edición. México: INEE

INEE (2017) La educación obligatoria en México. Informe 2017. México: INEE

INEE (2019) Panorama educativo de México, 2018. México: INEE.

INEGI (2020) Estadísticas a propósito del día del maestro (Docentes en educación básica en Mexico, datos nacionales), Retrieved from: https://www.inegi.org.mx/contenidos/saladeprensa/aproposito/ 2020/EAP_Maestro2020.pdf

INEGI (2021) Encuesta para la medicion del impacto COVID-19 en educación (ECOVID-ED), Retrieved from: https://www.inegi.org.mx/investigacion/ecovided/2020/

Kessler G (2002) La experiencia escolar fragmentada. Estudiantes y docentes en la escuela media en Buenos Aires, UNESCO, Buenos Aires.

Kim LE, Asbury K (2020) 'Like a rug had been pulled from under you': the impact of COVID-19 on teachers in England during the first six weeks of the UK lockdown. Br J Educ Psychol 90:10621083. https://doi.org/10.1111/bjep.12381

Kinman G, Wray S, Strange C (2011) Emotional labour, burnout and job satisfaction in UK teachers: the role of workplace social support. Educ Psychol 31(7):843-856. https://doi.org/10.1080/01443410. 2011.608650

Klaproth F, Federkeil L, Heinschke F, Jungmann T (2020) Teachers' experiences of stress and their coping strategies during COVID-19 induced distance teaching. Journal of Pedagogical Research 4(4) 444-452. https://doi.org/10.33902/JPR.2020062805

Krüger N (2011) The segmentation of the argentine education system: evidence from PISA 2009. Regional and Sectorial Economic Studies 11(3):41-64

Mejoredu (2020) Experiencias de las comunidades educativas durante la contingencia sanitaria por COVID-19. Educación media superior, Ciudad de Mexico, Retrived from: https://www.mejoredu. gob.mx/images/publicaciones/experiencias-ems.pdf

OECD (2020) COVID-19 in Latin America and the Caribbean: Regional socioeconomic implications and policy priorities, Retrieved from: https://www.oecd.org/coronavirus/policy-responses/covid-19-inlatin-america-and-the-caribbean-regional-socio-economic-implications-and-policy-priorities-93a64 fde/

OECD (2021) The state of school education: one year into the COVID pandemic. OECD Publishing, Paris, Retrieved from: https://www.oecd-ilibrary.org/education/the-state-of-school-education_201dd e84-en?_ga=2.128315084.1502888423.1625480266-1088927282.1613464059 
Palacio-Mejía LS, Wheatley-Ferández JL, Ordóñez-Hernández I, López-Ridaura R, López Gatel-Ramírez H, Hernández-Ávila M, Herdnández-Ávila JE (2021) Estimación del exceso de mortalidad por todas las causas durante la pandemia del COVID-19 en México. Salud Pública de México 63(2), 211-224. https://doi.org/10.21149/12225

Ruiz JI (1999) Metodología de la investigación cualitativa. Universidad de Deusto

Secretaría de Salud. (2021). Exceso de Mortalidad en México - Coronavirus. https://coronavirus.gob.mx/ exceso-de-mortalidad-en-mexico/

Saraví G (2015) Unequal inclusion: experiences and meanings of school segmentation in Mexico. Int J Educ Dev 45:152-160. https://doi.org/10.1016/j.ijedudev.2015.09.013

Tsang KK (2013) Teacher emotions: sociological understandings. Research Studies in Education 11:127-143

UNESCO (2020) COVID-19 educational disruption and response, UNESCO website, https://en.unesco. org/covid19/educationresponse (accessed on 25 June 2020).

Villa Lever L, Canales Sánchez A, Hamui Sutton M, Roqueñí Ibargüengoytia M del C (2017) Expresiones de las desigualdades sociales en espacios universitarios asimétricos. Instituto de Investigaciones Sociales: Consejo Nacional de Ciencia y Tecnología. http://ru.iis.sociales.unam.mx/jspui/ bitstream/IIS/5290/1/expresiones_desigualdades.pdf 